\title{
Effect of Game-Based Balance Training with CIMT on Pain, Muscle Strength, Range of Motion and Dynamic Balance in Female Patients with Total Knee Replacement
}

\author{
Hyo Bin Lee', Ho Suk Choi², Won Seob Shin² \\ 'Department of Physical Therapy, Graduate School of Health and Medicine, Daejeon University, Daejeon; ${ }^{2}$ Department of Physical Therapy, College \\ of Health and Medical Science, Daejeon University, Daejeon, Korea
}

Purpose: The aims of this study were to determine if game-based training with constraint-induced movement therapy (CIMT) is effective in improving the balance ability in female patients with a total knee replacement, and to provide clinical knowledge of CIMT game-based training that allows the application of total knee replacement.

Methods: Thirty-six patients who had undergone a total knee replacement were assigned randomly to CIMT game training $(n=12)$, general game training $(n=12)$, and self-exercise $(n=12)$ groups. All interventions were conducted 3 times a week for 4 weeks. All patients used a continuous passive motion machine 5 times a week and 2 times a day for 4 weeks. The visual analog scale (VAS), muscle strength of knee flexion and extension, and range of motion (ROM) of knee flexion and extension were assessed, and the functional reach test (FRT), and timed up and go (TUG) test were performed to evaluate the balance ability.

Results: All 3 groups showed significant improvement in the VAS, knee flexion and extension muscle strength, FRT, and TUG test after the intervention $(p<0.05)$. Post hoc analysis revealed significant differences in FRT, and TUG of the CIMT game training group compared to the other group $(p<0.05)$.

Conclusion: Although the general game training and CIMT game training improved both the knee extension muscle strength and dynamic balance ability, CIMT game training had a larger effect on dynamic balance control.

Keywords: Balance, Constraint-induced movement therapy, Total knee replacement

\section{서 론}

퇴행성 무릎 관절염은 우리나라 65 세 이상의 노인에게 나타나는 장 애 중에서 $53 \%$ 라는 높은 발생빈도를 가진 질환 중 하나이며, 진행성 과 비염증성 병변으로 구간골격과 사지를 침범하여 기능저하와 기 능상실을 유발한다. 또한 생활습관 개선과 약물, 물리요법 등의 보존 적 치료를 우선으로 적용하나, 더 이상 호전적인 관절의 변화가 없고 통증이 극심해진 경우, 수술적인 치료방법이 추천되고 있다. 퇴행성 무릎 관절염 치료를 대표하는 수술은 무릎인공관절수술이지만, 수 술 후에도 여전히 문제상황들이 존재한다. 환자는 수술한 다리의 무 릎신전 근력 감소와 무릎신전의 가동범위의 제한을 특징으로 하는 비대칭적인 움직임 패턴을 겪게 된다. ${ }^{2-5}$ 또한 수술을 한 환자의 $20 \%$ 는 여전히 무릎 통증을 느껴 반대쪽 하지에 체중을 싣게 되는 비대칭

Received Sep 13, 2018 Revised Oct 30, 2018

Accepted Oct 31, 2018

Corresponding author Won Seob Shin

E-mail shinws@dju.kr
적 체중부하가 발생한다. ${ }^{6}$ 결과적으로 수술한 무릎의 통증과 관절가 동범위의 제한, 근력 약화는 균형능력을 감소시킨다. ${ }^{6.7}$ 따라서 무릎 인공관절 수술 후 근력, 관절가동범위, 통증의 유무 뿐 만 아니라 균 형능력도 중요하므로 초기부터 균형능력을 위한 운동이 필요하다. ${ }^{8}$

최근에는 다양한 운동과 치료환경의 한계를 극복하고자 가상현 실과 게임을 이용한 연구방법들이 등장했고, 이를 이용한 균형과 인 지 발달을 위한치료 역시 꾸준히 증가하고 있다. 대표적인 게임 시스 템으로는 Nintendo Wii와 보조기구인 Wii balance board를 이용한 모 션 제어 게임이 있는데, 광범위한 연령대가 이용할 수 있으며 대중적 이고 비용이 저렴하다. ${ }^{10}$ 또한 기존의 재활 환경보다 환자들의 참여도 와 집중도를 증가시켰고, ${ }^{11}$ 균형에 초점을 맞춘 다양한 운동환경으로 활용되고 있다. ${ }^{12}$ 실제로 Nintendo Wii가 노인과 뇌졸중 환자들의 균 형재활에 치료도구로서 잠재력을 보여주었지만 정형외과 환자들에
Copylight (C) 2018 The Korea Society of Physical Therapy

This is an Open Access article distribute under the terms of the Creative Commons Attribution Non-commercial License (Http:// creativecommons.org/license/by-nc/4.0.) which permits unrestricted non-commercial use, distribution, and reproduction in any medium, provided the original work is properly cited. 
게 적용하고 중재한 연구는 드물다. 전방십자인대 재건술 ${ }^{13}$ 과 무릎인 공관절수술 후 ${ }^{14}$ 재활에서 Wii balance board를 이용한 방법이 통증, 관절가동범위 및 하지의 기능변화에서 기존의 치료효과와 차이가 없었다. 본 연구는 Nintendo Wii 시스템이 가지고 있는 고유의 운동환 경이 일반인을 대상으로 설정할 경우, 치료적 효과가 미비할 수 있음 을 인식하고, 특정 정형외과 환자들을 대상으로 하는 치료환경을 구 현하고자 노력했다. 기존의 Nintendo Wii 게임시스템은 비치료적 운 동대상인 일반인이 활용할 수 있도록 설정되었으므로 정형외과적 손상환자들의 재활을 위해 보다 강도 높은 자극을 줄 수 있는 치료 환경을 설정했다. 뇌졸중 환자의 마비측 사용을 더 증가시키기 위한 방법으로 강제 유도 운동 치료(constraint induced movement therapy) 가 있다. 강제 유도 운동 치료는 비마비측을 억제하고 마비측의 움직 임을 강제하는 것으로 효과적인 재활 방법 중 하나이다. 뇌졸중환자 의 비대칭적 체중부하를 개선하기 위한 연구에서 뇌졸중 환자의 정 적 및 동적균형 능력의 향상이 나타났다. 비대칭적 체중지지와 균형 능력의 감소를 특징으로 하는 무릎인공관절 수술 환자에게도 이것 들을 개선하기 위한 다양한 중재가 있었지만 정형외과적 손상에 따 른 하지의 민감도를 달리 적용한 강제 유도 운동 치료 개념의 중재를 적용한 연구는 드물다.

따라서 본 연구의 목적은 강제 유도 운동 치료를 적용한 가상현실 기반의 게임훈련이 한 쪽 다리에 무릎인공관절 수술을 한 여성환자 들의 통증, 근력, 능동관절가동범위 및 동적균형에 미치는 영향을 알 아보고자 한다.

\section{연구방법}

\section{1. 연구대상}

본 연구의 대상자는 천안시에 위치한 $\mathrm{C}$ 병원에서 한 쪽 다리에 무릎 인공관절수술을 한 입원환자들을 대상으로 실시하였다. 대상자는 퇴행성 무릎관절염 진단을 받아 무릎 인공관절 수술을 하고 일주일 이 경과한 자, 선 자세에서 수술 측 하지의 통증이 심하지 않은 자, 구 두적 지시에 정확하게 반응할 수 있는 자로 선정기준을 삼았다. 또한 2 번 혹은 그 이상의 낙상 경험이 있는 자, 심각한 시각장애가 있는 자 는 본 연구에서 제외하였다. 표본크기의 결정을 위해 예비연구를 시 행하였고 그 결과 효과크기는 0.55 에서 0.6 으로 나타났다. $\mathrm{G}^{*}$ power (version 3.1.9.2; Germany)을 이용하여 alpha 0.05 , 검정력 0.8 일 때 각 표 본의 집단은 10 명이었고, 탈락률 $20 \%$ 를 고려하여 총 36 명의 대상자 수로 결정하였다. 대상자 선정조건에 만족하는 대상자는 총 36 명으 로 강제 유도 운동 치료 게임훈련군 12 명, 일반적 게임훈련군 12 명, 자 가운동군 12 명으로 무작위 배정하였다. 모든 대상자는 연구의 목적 과 과정에 충분한 설명을 듣고 실험 참여에 자발적으로 동의하였다.
본 연구의 모든 절차와 방법은 대전대학교의 기관생명윤리위원회의 심의를 거쳐 진행하였다(IRB 1040647-201712-HR-005).

\section{2. 실험방법}

\section{1) 측정도구}

(1) 시각통증척도(visual analogue scale)

시각통증척도는 설문지에 한 쪽 끝은 ‘통증 없음' 다른 한 쪽 끝은 ‘참 을수 없는 극심한 통증으로 표시되어있는 $10 \mathrm{~cm}$ 의 선에 환자가 직접 표시하도록 하였다.

(2) 근력 및 관절가동범위(muscle strength and range of motion) 무릎관절의 굴곡과 신전의 근력 평가를 위해 도수 근력 검사를 시행 하였다. 도수 근력 검사는 10 점 척도를 이용하여 시행되었다. 자의 신 전근 근력 평가는 치료용 테이블에 대상자가 걸터앉아 최대한 무릎 을 신전 시킨다. 그리고나서 평가자는 대상자의 발목 위쪽에 무릎의 굴곡 방향으로 최대 저항을 주었고 대상자는 신전 자세를 5 초간 유 지하도록 하였다. 굴곡근 근력 평가는 테이블 위에 엎드린 자세에서 치료사의 한 손은 허벅지에 나머지 한 손은 발목 위에 저항을 주고 대상자는 굴곡 자세를 5 초간 유지하도록 하였다. 굴곡과 신전 모두 3 점 이하일 경우, 옆으로 누운 자세에서 시행되었다. ${ }^{15}$ 무릎관절의 가 동범위의 측정은 각도계(Goniometer, Kineman Enterprises, USA)를 사 용하여 굴곡과 신전 각도를 측정하였다. 복와위에서 대퇴골의 외측 상과를 축으로 대퇴골의 대전자와 이어지는 선과 비골의 외복사뼈 와 이어지는 선을 기준으로 하여 통증이 없는 범위 내에서 능동관절 가동 범위를 측정하였다.

\section{(3) 동적 균형(dynamic balance)}

기능적 팔 뻗기 검사는 앞으로 이동하는 체중을 평가하기 위해 노인 과 뇌졸중 환자에게 임상에서 흔히 사용하고 있으며 간편하게 동적 균형을 평가하는 방법이다. 대상자들은 어깨넓이로 두 발을 벌리고 벽 옆에 선다. 시작자세는 어깨관절을 90 도 굽히고 팔꿈치와 손을 뻗 도록 하는 것이다. 그 후 평행을 유지한 상태로 최대한 몸통을 앞으 로 구부리도록 한다. 시작자세에서 세 번째 중수관절 끝 지점과 몸통 을 최대한 구부렸을 때 손가락 끝 지점 사이의 거리 $(\mathrm{cm})$ 변화를 측정 하였다. 기능적 팔 뻗기 검사는 측정자 간 신뢰도 $(\mathrm{r}=0.98)$ 와 측정자 내 신뢰도 $(\mathrm{r}=0.89)$ 가 높은 검사방법으로 신뢰할 만한 도구로 알려져 있다. ${ }^{16}$ 일어나 걸어가기 검사는 기능적인 운동성과 동적 균형을 빠르 게 측정할 수 있는 평가이다. 측정자가 신호를 주면 대상자는 팔걸이 가 있는 의자에 앉아있다가 의자에서 일어난 후, 전방 $3 \mathrm{~m}$ 거리를 걸 은 뒤 다시 되돌아와 의자에 앉는 시간(초)을 측정하였다. 이 검사는 1 회 연습과정을 거친 후 3 회 반복 측정하여 평균값을 기록하였다. 검 
사 시 보행 보조도구를 사용하지만, 치료사의 보조는 받지 않았다. 일어나 걸어가기 평가의 측정자 내 신뢰도는 $r=0.99$ 이고, 측정자 간 신뢰도는 $r=0.98$ 이다. ${ }^{17}$

\section{2) 실험절차}

강제 유도 운동 치료 게임 훈련군은 닌텐도 사의 위 핏 게임 시스템의 슬라롬 스키(Slalom ski)와 축구 헤딩 프로그램을 사용하였다. 슬라 롬 스키는 좌·우로 체중을 이동하여 캐릭터가 깃발 사이를 통과하 는 게임이다. 또한 축구 헤딩도 날아오는 축구공을 좌 - 우로 체중을 이용하여 헤딩하는 프로그램이다. 대상자는 두 개의 Wii balance board 중심에 각 한발씩 올려놓고 게임훈련을 하였다. 두 Wii balance board의 중심 간 거리는 $31 \mathrm{~cm}$ 이다. 하나의 Wii balance board는 $49.5 \times$ $30.5 \times 5.1$ 의 크기를 가지며 사용가능면적은 $43.3 \times 23.8 \mathrm{~cm}$ 이다..$^{8}$ 보드 에 있는 4 개의 압력센서가 각 끝의 모서리에 위치하여 부하되는 무게 를 측정하게 된다. 따라서 두 개의 Wii balance board에서 측정된 총 8 개의 신호는 블루투스를 통해 컴퓨터에 수집된다. 컴퓨터에서 수집 된 신호는 Matlab 프로그램을 이용하여 각 하지의 압력 중심을 계산 한다. ${ }^{19}$

측정된 압력중심은 아래의 식에 따라 가상의 압력중심으로 계산 되어 Arduino Duemilanove card를 통해 세 번째 Wii balance board로 전송된다.

가상-압력중심 $=\alpha \times$ 비 수술측-압력중심 $+\beta \times$ 수술측-압력중심

세 번째 Wii balance board에서 Wii의 본체로 신호를 보내어 게임 캐 릭터를 조절하게 된다. 본 연구에서는 비 수술측 민감도 $\alpha$ 값은 1.2 로 설 정되었으며, 수술측 민감도 $\beta$ 값은 1 로 설정되었다. 이것은 비 수술측 압력중심 이동의 정도를 증가시켜 게임 훈련을 하는 동안 비 수술측으 로의 체중지지를 감소시키게 되어 수술측에 체중지지를 증가시킨다.

일반적인 게임 훈련군은 강제 유도 운동 치료 게임 훈련군과 동일한 닌텐도 사의 위 핏 게임 시스템의 슬라롬 스키와 축구 헤딩 프로그램 을 사용하였지만 게임훈련 시 하나의 Wii balance board를 압력 중심의 수정없이 사용하였다. 강제 유도 운동 치료 게임 훈련군과 일반적인 게 임 훈련군 모두 환자의 양 발의 거리는 환자의 어깨 넓이로 시행하였다. 두 군 모두 총 4 주간, 주 3 회, 하루 30 분 게임 훈련을 실시하였다.
자가운동군은 환자들에게 발 뒷꿈치 들기, 벽에 기댄 채 $1 / 2$ 스쿼 트, 앉은 상태에서 일어나기, 한 발 들고 서기 운동을 시행하였다. 연 구 시작 시 치료사는 각 운동에 대한 자세와 정량을 정확히 설명하였 고, 운동방법이 적힌 프린트와 운동을 완료했음을 기록하는 체크리 스트를 배포하였다. 자가운동의 한 사이클 적용 시 총량은 30 분으로 계획되었으며주 3 회 시행하도록 격려하였다.

모든 무릎 인공관절수술 환자들은 공통적으로 총 4주, 주 5 회, 하 루 2 회, 1 회 30 분씩 지속적 수동 운동기(CPM)를 실시하였다.

\section{4. 분석방법}

모든 자료는 SPSS ver. 20.0 통계 프로그램을 이용하였고 대상자에 일반 적 특성의 정규분포를 알아보기 위해 단일표본 Kolmogorov-Smirnov 로 정규성 검정을 하였다. 중재 전과 후 군 내 차이는 대응표본 $\mathrm{t}$ 검정 (paired t-test)을, 중재 전과 후의 군 간 차이는 일원배치분산분석(oneway AVOVA)을 사용하였으며 사후검정으로 Shceffe 다중비교분석을 하였다. 모든 통계학적 유의수준은 0.05 로 설정하였다.

\section{결 과}

\section{1. 연구대상자의 일반적 특성}

본 연구에 참여한 전체 대상자는 총 36 명으로 강제 유도 운동 치료 게임 훈련군 12 명, 일반적 게임 훈련군 12 명과 자가 운동군 12 명으로 무작위 배정되었다. 세 군 간의 연령, 키, 체중, 수술측 간에 유의한 차 이는 없었다 $(\mathrm{p}>0.05)$. 각 군은 무릎 인공관절 수술날짜와 훈련시작 날짜사이의 기간이 강제 유도 운동 치료 게임 훈련군은 $10.25 \pm 2.34$ 일, 일반적 게임훈련군은 $10.42 \pm 1.68$ 일, 자가 운동군은 $11.25 \pm 2.30$ 일 이다. 무릎 인공관절 수술날짜와 운동시작 날짜 사이의 기간에서 세 군 간 유의한 차이가 없었다 $(\mathrm{p}>0.05)$. 연구대상자의 일반적 특성은 다음과 같다(Table 1).

\section{2. 대상자의 통증, 근력 및 관절가동범위 변화}

연구 대상자들의 중재 전후 통증은 세 군 모두 통계적으로 유의하게 감소하였으나 $(\mathrm{p}<0.05)$, 세 군 간의 변화량 비교에서는 사후 분석 결

Table 1. General characteristics of subjects

\begin{tabular}{|c|c|c|c|c|}
\hline & $\begin{array}{l}\text { CIMT game training } \\
\text { group }(n=12)\end{array}$ & $\begin{array}{c}\text { General game training } \\
\text { group }(n=12)\end{array}$ & $\begin{array}{l}\text { Self-exercise } \\
\text { group }(n=12)\end{array}$ & $\mathrm{X}^{2} / \mathrm{F}$ \\
\hline Age (year) & $69.58 \pm 3.94^{a}$ & $70.17 \pm 6.18$ & $73.58 \pm 6.71$ & 1.703 \\
\hline Height $(\mathrm{cm})$ & $153.78 \pm 8.75$ & $151.27 \pm 5.35$ & $151.63 \pm 8.13$ & 0.388 \\
\hline Weight (kg) & $64.42 \pm 10.73$ & $69.43 \pm 7.10$ & $61.73 \pm 7.48$ & 2.482 \\
\hline Start date of training to post-operative (day) & $10.25 \pm 2.34$ & $10.42 \pm 1.68$ & $11.25 \pm 2.30$ & 0.761 \\
\hline Affected side (Right/Left) & $4 / 8$ & $7 / 5$ & $6 / 6$ & 1.560 \\
\hline
\end{tabular}

${ }^{\mathrm{a}}$ mean $\pm \mathrm{SD}$. 
과 군 간 유의한 차이는 없었다( $\mathrm{p}>0.05)$. 세 군 모두 무릎 굴곡근력과 신전근력이 중재 전후 유의하게 증가 하였지만 $(\mathrm{p}<0.05)$, 무릎 굴곡 근 력은 세 군 간의 변화량 비교에서 통계적으로 유의한 차이가 없었다 ( $\mathrm{p}>0.05)$. 그러나 무릎 신전 근력은 변화량 비교에서 사후검정 결과, 강제 유도 운동 치료 게임 훈련군과 일반적 게임 훈련군이 자가 운동 군보다 유의하게 더 증가 하였다 $(\mathrm{p}<0.05)$. 무릎 신전 및 굴곡 관절가 동범위는 중재 전·후 유의하게 증가하였지만 $(\mathrm{p}<0.05)$, 군 간 변화량 비교에서는 유의한 차이가 없었다( $\mathrm{p}>0.05)($ Table 2).

\section{3. 대상자의 동적균형능력 변화}

동적 균형 능력 비교 중 기능적 팔 뻗기 검사는 중재 전후 군 내 차이 는 통계적으로 유의한 증가가 있었고 $(\mathrm{p}<0.05)$, 사후 분석 결과 세 군 간의 변화량은 강제 유도 운동 치료 게임 훈련군이 일반적 게임 훈련 군과 자가운동군과 비교하여 유의한 증가가 있었다 $(\mathrm{p}<0.05)$. 세 군 간의 일어나 걸어가기 검사의 결과 세 군의 중재 전후 일어나 걸어가 기 평가에 통계적으로 유의한 감소가 있었다 $(\mathrm{p}<0.05)$. 일어나 걸어가 기 검사의 변화량에서 사후 분석 결과 강제 유도 운동 치료 게임 훈

Table 2. Comparison of changes in three groups before and after training on pain, muscle strength and active range of motion

\begin{tabular}{|c|c|c|c|c|c|}
\hline & & $\begin{array}{l}\text { CIMT game training } \\
\text { group }(n=12)\end{array}$ & $\begin{array}{l}\text { General game training } \\
\text { group }(n=12)\end{array}$ & $\begin{array}{l}\text { Self-exercise group } \\
\qquad(n=12)\end{array}$ & $\mathrm{F}$ \\
\hline \multirow[t]{4}{*}{$\operatorname{VAS}(\mathrm{cm})$} & Pre & $9.67 \pm 0.65$ & $9.25 \pm 1.29$ & $9.33 \pm 0.89$ & 0.609 \\
\hline & Post & $5.25 \pm 1.66^{*}$ & $5.75 \pm 1.92^{*}$ & $4.92 \pm 1.88^{*}$ & 0.637 \\
\hline & t & 9.781 & 8.385 & 7.571 & \\
\hline & Change & $4.42 \pm 1.56$ & $3.50 \pm 1.45$ & $4.42 \pm 2.02$ & 1.170 \\
\hline \multirow[t]{4}{*}{ Knee flexion strength (score) } & Pre & $2.25 \pm 6.22$ & $2.08 \pm 0.52$ & $2.00 \pm 0.60$ & 0.575 \\
\hline & Post & $4.17 \pm 1.19^{\star}$ & $3.67 \pm 0.49^{\star}$ & $3.58 \pm 0.52^{*}$ & 1.855 \\
\hline & t & -5.702 & -6.917 & -6.092 & \\
\hline & Change & $-1.92 \pm 1.17$ & $-1.58 \pm 0.79$ & $-1.58 \pm 0.90$ & 0.477 \\
\hline \multirow[t]{4}{*}{ Knee extension strength (score) } & Pre & $2.17 \pm 0.72$ & $2.088 \pm 0.52$ & $2.00 \pm 0.60$ & 0.219 \\
\hline & Post & $4.58 \pm 0.90^{*}$ & $4.42 \pm 0.90^{\star}$ & $3.33 \pm 0.49^{*}$ & 1.855 \\
\hline & t & -12.522 & -6.567 & -5.933 & \\
\hline & Change & $-2.42 \pm 0.67^{+}$ & $-2.23 \pm 1.23^{+}$ & $-1.33 \pm 0.79$ & 5.094 \\
\hline \multirow[t]{4}{*}{ Knee flexion AROM $\left(^{\circ}\right)$} & Pre & $60.42 \pm 12.33$ & $59.17 \pm 12.40$ & $54.17 \pm 11.04$ & 0.920 \\
\hline & Post & $95.42 \pm 16.71^{*}$ & $86.67 \pm 15.13^{*}$ & $76.67 \pm 16.00^{\star}$ & 4.146 \\
\hline & $\mathrm{t}$ & -7.532 & -5.652 & -4.700 & \\
\hline & Change & $-35.00 \pm 16.10$ & $-27.50 \pm 16.86$ & $-22.50 \pm 16.58$ & 1.742 \\
\hline \multirow[t]{4}{*}{ Knee extension AROM $\left({ }^{\circ}\right)$} & Pre & $132.92 \pm 15.73$ & $127.50 \pm 12.15$ & $126.25 \pm 12.64$ & 0.815 \\
\hline & Post & $167.08 \pm 10.97^{*}$ & $162.08 \pm 11.17^{*}$ & $157.92 \pm 8.38^{*}$ & 2.405 \\
\hline & t & -7.429 & -7.349 & -8.102 & \\
\hline & Change & $-34.17 \pm 15.93$ & $-34.58 \pm 16.30$ & $-31.67 \pm 13.54$ & 0.127 \\
\hline
\end{tabular}

Values are mean $\pm S D$.

CIMT: constraint-induced movement therapy, VAS: visual analogue scale, AROM: active range of motion.

*significant difference pre and post training, ${ }^{+}$significant difference with self-exercise group.

Table 3. Comparison of changes in three groups before and after training on dynamic balance

\begin{tabular}{|c|c|c|c|c|c|}
\hline & & $\begin{array}{l}\text { CIMT game training } \\
\text { group }(n=12)\end{array}$ & $\begin{array}{l}\text { General game training } \\
\text { group }(n=12)\end{array}$ & $\begin{array}{l}\text { Self-exercise } \\
\text { group }(n=12)\end{array}$ & $F$ \\
\hline \multirow[t]{4}{*}{ FRT (cm) } & Pre & $7.96 \pm 3.08$ & $7.88 \pm 3.23$ & $7.33 \pm 3.03$ & 0.143 \\
\hline & Post & $22.08 \pm 5.09^{*}$ & $15.75 \pm 7.63^{*}$ & $9.50 \pm 3.34^{*}$ & 14.956 \\
\hline & $\mathrm{t}$ & -9.064 & -3.872 & -3.350 & \\
\hline & Change & $-14.13 \pm 5.40^{+\neq}$ & $-7.88 \pm 7.05^{\ddagger}$ & $-2.17 \pm 2.24$ & 15.369 \\
\hline \multirow[t]{4}{*}{ TUG (sec) } & Pre & $63.09 \pm 10.39$ & $55.33 \pm 18.43$ & $55.08 \pm 10.64$ & 1.331 \\
\hline & Post & $11.66 \pm 2.51^{*}$ & $19.93 \pm 6.20^{*}$ & $36.07 \pm 10.03^{*}$ & 38.160 \\
\hline & $\mathrm{t}$ & 16.907 & 6.569 & 6.622 & \\
\hline & Change & $-51.43 \pm 10.54^{+\neq}$ & $-35.41 \pm 18.67^{\ddagger}$ & $-19.01 \pm 9.94$ & 16.937 \\
\hline
\end{tabular}

Values are mean \pm SD.

CIMT: constraint-induced movement therapy, FRT: functional reach test, TUG: timed up go test.

* significant difference pre and post training, ${ }^{+}$significant difference with general game training group, ${ }^{*}$ significant difference with self-exercise group. 
련군이 일반적 게임 훈련군과 자가운동군과 비교하여 유의한 차이 가 나타났다 $(\mathrm{p}<0.05)$ (Table 3$)$.

\section{고 찰}

본 연구는 한 쪽 다리에 무릎인공관절 수술을 한 여성환자를 대상으 로 강제 유도 운동 치료를 동반한 가상현실게임이 통증, 근력과 관절 가동범위 및 동적 균형에 어떠한 영향을 미치는지 연구하였다. 본 연 구의 결과 무릎관절의 전치환술 후 재활을 위한 강제 유도 운동 치료 게임 훈련 적용 이후에 통증, 관절가동범위는 일반적 게임 훈련군과 자가 운동군과 비교하여 차이가 없었지만, 동적 균형능력에서 두 군 과비교하여차이가 나타났다.

신경계손상 환자 특히 뇌졸중 편마비 환자에게 많이 사용되는 강 제 유도 운동 치료 개념의 치료를 균형 훈련 게임과 결합하였다. 하지 에 강제 유도 운동 치료를 적용하여 비 수술측 하지의 기능적인 제한 으로 사용빈도를 낮춰 수술측 하지의 체중부하를 늘렸다. 이로써 상 지 재활에 많이 사용되는 강제 유도 운동 치료와 같은 효과를 정형 외과 환자에게서 얻고자 하였다. ${ }^{19}$ 일반적으로 뇌졸중 환자에게 강제 유도 운동 치료를 상지에 적용 시킬 때 슬링이나 글러브 등 도구를 이 용해 움직임을 억제한다. 하지만 하지에 도구를 이용한 방법은 움직 임을 방해하고 자세의 안정성 유지가 어렵기 때문에 하지에 강제 유 도 운동치료를 적용하기 위해선 고정이 없어야 한다.19-21

무릎 인공관절 수술 후 통증은 시간의 경과와 밀접한 관련이 있고, 초기에는 거의 모든 환자에게 통증이 있지만 기간이 경과함에 따라 점점 소실되는 경향이 있다. ${ }^{22}$ 또한 환자의 키, 체중 및 체질량지수, 수 술 전 hospital for special surgery knee score 점수, 감염의 위험인자인 고 령, 영양부족, 스테로이드 사용, 오랜 시간의 병원 생활 및 당뇨병, 류 마티스 관절염, 건선 등 전신적인 상태에 의해 영향을 받을 수 있지만, 그보다는 환자의 성격과 심리적 상태도 매우 중요하다고 볼 수 있 다. 23.24 본 연구에서도 중재 전과 후 통증의 변화량이 군 내에서는 시 간경과에 따라 통계학적으로 유의한 차이를 보였지만, 군 간 변화량 에서는 유의한차이를 발견하지 못했다.

무릎 관절 신전근의 근력이 중재 전후, 군간 에서 모두 유의하게 증 가한 결과를 나타냈다. 무릎관절의 신전 능력은 양쪽 하지의 체중지 지 능력을 결정하는 핵심 요소이다. 그렇기 때문에 수술 이후 걷기, 계단 이동 등 여러 과제 수행을 효과적으로 시행하고 일상생활과 취 미생활을 다시 하기위해 필수적인 요소이다.,625,26 비디오게임을 통해 체중이동 훈련을 하여 노인의 하지의 근력과 균형증진이 이뤄진 한 선행연구에서는 실험군의 무릎관절 신전근인 대퇴사두근의 근력이 좌측 $17.11 \pm 3.04 \mathrm{~kg}$ 에서 $21.66 \pm 4.35 \mathrm{~kg}$ 으로, 우측은 $18.38 \pm 3.24 \mathrm{~kg}$ 에 서 $21.44 \pm 3.47 \mathrm{~kg}$ 으로 모두 통계학적으로 유의한 차이가 있었다.27 이
는 게임프로그램을 통해 무릎에서 구심성 및 원심성 근육 수축이 발 생하고 이를 동반한 체중이동이 무릎 신전근의 근력 향상에 영향을 주었다. 또한 여성 노인을 대상으로 실시한 연구에서 동적 체중 이동 하기, 좁게 또는 넓게 걷기 등의 균형 능력 향상을 위한 중재가 근력 향상에도 영향을 주었다. ${ }^{28}$ 이와 같이 본 연구에서도 슬라롬 스키와 축구 헤딩 프로그램의 균형훈련을 수행하는 동안 질량중심을 이동 하였다. 신체의 질량중심을 이동할 때, 하지를 안전하고 효과적으로 사용해야 하기 때문에 엉덩이, 무릎, 발목의 신전 모멘트에 대해 근육 이 지속적으로 사용되어 신전 근력의 향상에 도움을 주었고 더 나아 가 기능적인 움직임의 향상에도 영향을 준 것으로 생각된다. ${ }^{26}$

무릎인공관절수술 전 무릎관절 굴곡 변형과 환자의 체중이 수술 후 무릎 관절 운동 범위에 영향을 미친다고 보고하였으며.29 수술 후 초기 1 년간은 체질량 지수, 유병기간, 수술 전 관절변형 정도가 무릎 관절 운동범위에 의미있게 영향을 미치며 수술 직후부터 시작되는 운동의 순응도면에서 차이가 있는것으로 보고되었다. ${ }^{30}$ 본 연구에서 는 중재 전과 후 시간 경과에 따른 군 내 유의한 차이가 있었다. 그러 나 중재 전과 후 군 간 통계학적으로 유의한 차이가 발견되지 않았다. 이 결과는 세 군 모두 수술 이후 조기에 적용된 중재로써 환자의 주 변 연부 조직의 적응이 관절 운동에 영향을 주어 가동범위의 변화가 있었지만, 본 연구에서 진행된 게임훈련과 자가운동에 따른 차이는 나타나지 않았다.

동적균형능력의 변화를 알아보기 위해 기능적 팔 뻗기와 일어나 걸어가기 검사를 측정하였는데 세 군 모두 중재 전과 후 유의한 변화 가 나타났고, 세 군 간 비교에서도 유의한 차이를 보였다. 이는 게임 기반의 운동 프로그램이 시각과 고유수용성감각의 피드백을 이용 한 훈련으로 동적 균형능력에 유의한 차이를 나타낸 결과가 운동성 증진에도 영향을 미치게 된 연구와 유사하다. ${ }^{31}$ 또다른 선행연구에서 도 4 주간의 가상현실게임을 이용한 균형훈련이 노인의 정적, 동적 균 형변화에서 모두 통계적으로 유의하다고 보고되었으며, ${ }^{22}$ 이러한 가 상현실기반의 중재 후에 정적 균형능력이 유의하게 개선되었는데 전 후 자세동요보다 좌우 자세동요에서의 감소에 더 효과가 있었다. ${ }^{33}$ 또 한 뇌졸중 환자를 대상으로 한 가상현실기반의 중재에서는 정적 안 정성과 안정성의 한계를 유의하게 향상시켰는데, 이는 발목전략을 이용한 마비측과 비 마비측의 체중이동이 효과적으로 나타났기 때 문이라고 하였다. ${ }^{34}$ 따라서 본 연구에서 강제 유도 운동 치료를 기반 으로 한 가상현실게임 중재가 환자의 적극적인 참여를 이끌어냈고, 무릎 신전 움직임을 통한 신전 근력 향상과 체중이동 훈련이 효과적 으로 이어져 환자의 동적 균형능력을 향상시켰다고 생각한다.

본 연구의 제한점은 수술 이후 4-5주 이내에 환자가 퇴원하기 때문 에 추적 관찰을 하지 않은 점, 수술 후 조기에 중재를 적용하여 통증 유발과 위험 요인 인자를 배제하기 위해 좀 더 난이도 높은 게임 중재 
를 적용하지 못한 점, 단일병원에서 중재가 이뤄졌다는 점이다. 향후 연구에서는 좀 더 다양한 난이도의 게임 적용과 강제 유도 운동 치료 게임 훈련 후 대상자의 다양화, 일상생활동작, 심리적 요소 평가 등 다양한 후속연구가 계속 되었으면 한다.

강제 유도 운동 치료를 적용한 게임 훈련은 일반적인 게임훈련이나 자가운동과 비교하여 동적균형능력향상에 보다 효과적으로 신경계 손상 환자뿐만 아니라 정형외과적 손상 환자에게도 적용 가능하다.

\section{ACKNOWLEDGEMENTS}

이 성과는 2016년도 정부(미래창조과학부)의 재원으로 한국연구재 단의 지원을 받아 수행 된 연구임(No. 2016R1C1B2010420).

\section{참고문헌}

1. Cho WS, Youm YS, Yang BS. The causes of revision total knee arthroplasty. J Korean Orthop Assoc. 2007;42(2):216-20.

2. Boonstra MC, Schwering PJ, De Waal Malefijt MC et al. Sit-to-stand movement as a performance-based measure for patients with total knee arthroplasty. Phys Ther. 2010;90(2):149-56.

3. Hatfield GL, Hubley-Kozey CL, Wilson JLA et al. The effect of total knee arthroplasty on knee joint kinematics and kinetics during gait. J Arthroplasty. 2011;26(2):309-18.

4. Meretta BM, Whitney SL, Marchetti GF et al. The five times sit to stand test: Responsiveness to change and concurrent validity in adults undergoing vestibular rehabilitation. J Vestib Res. 2006;16(4, 5):233-43.

5. Yoshida Y, Zeni Jr J, Snyder-Mackler L. Do patients achieve normal gait patterns 3 years after total knee arthroplasty? J Orthop Sports Phys Ther. 2012;42(12):1039-49.

6. Christensen JC, Mizner RL, Foreman KB et al. Quadriceps weakness preferentially predicts detrimental gait compensations among common impairments after total knee arthroplasty. J Orthop Res. 2018.

7. Harato K, Nagura T, Matsumoto H et al. Extension limitation in standing affects weight-bearing asymmetry after unilateral total knee arthroplasty. J Arthroplasty. 2010;25(2):225-9.

8. Gage WH, Frank JS, Prentice SD et al. Postural responses following a rotational support surface perturbation, following knee joint replacement frontal plane rotations. Gait Posture. 2008;27(2):286-93.

9. Stratton G, Ridgers N. Energy expenditure in adolescents playing new generation computer games. Br J Sports Med. 2008;42(7):592-4.

10. Lange B, Flynn S, Proffitt R et al. Development of an interactive gamebased rehabilitation tool for dynamic balance training. Top Stroke Rehabil. 2010;17(5):345-52.

11. Nitz J, Kuys S, Isles R et al. Is the Wii Fit ${ }^{\mathrm{TM}}$ a new-generation tool for improving balance, health and well-being? A pilot study. Climacteric. 2010; 13(5):487-91.

12. Deutsch JE, Borbely M, Filler J et al. Use of a low-cost, commercially available gaming console (Wii) for rehabilitation of an adolescent with cerebral palsy. Phys Ther. 2008;88(10):1196-207.
13. Baltaci G, Harput G, Haksever B et al. Comparison between Nintendo Wii Fit and conventional rehabilitation on functional performance outcomes after hamstring anterior cruciate ligament reconstruction: Prospective, randomized, controlled, double-blind clinical trial. Knee Surg Sports Traumatol Arthrosc. 2013;21(4):880-7.

14. Fung V, Ho A, Shaffer J et al. Use of Nintendo Wii Fit ${ }^{\mathrm{TM}}$ in the rehabilitation of outpatients following total knee replacement: a preliminary randomised controlled trial. Physiotherapy. 2012;98(3):183-8.

15. Kendall FP, McCreary EK, Provance PG et al. Muscles, testing and function: with posture and pain. Baltimore, Williams \& Wilkins, 1993.

16. Duncan PW, Weiner DK, Chandler J et al. Functional reach: a new clinical measure of balance. J Gerontol. 1990;45(6):192-7.

17. Podsiadlo D, Richardson S. The timed "up \& go": a test of basic functional mobility for frail elderly persons. J Am Geriatr Soc. 1991;39(2):142-8.

18. Leach JM, Mancini M, Peterka RJ et al. Validating and calibrating the Nintendo Wii balance board to derive reliable center of pressure measures. Sensors. 2014;14(10):18244-67.

19. Choi HS, Shin WS, Bang DH et al. Effects of game-based constraint-induced movement therapy on balance in patients with stroke: a single-blind randomized controlled trial. Am J Phys Med Rehabil. 2017;96(3):184-90.

20. Numata K, Murayama T, Takasugi J et al. Effect of modified constraintinduced movement therapy on lower extremity hemiplegia due to a higher-motor area lesion. Brain Inj. 2008;22(11):898-904.

21. Ding Q, Stevenson IH, Wang N et al. Motion games improve balance control in stroke survivors: a preliminary study based on the principle of constraint-induced movement therapy. Displays. 2013;34(2):125-31.

22. Cho WS, Ahn HS, Kim MY et al. Pain after total knee arthroplasty. J Korean Orthop Assoc. 2006;41(1):129-33.

23. Mahomed NN, Liang MH, Cook EF et al. The importance of patient expectations in predicting functional outcomes after total joint arthroplasty. J Rheumatol. 2002;29(6):1273-9.

24. Wilson MG, Kelley K, Thornhill T. Infection as a complication of total knee-replacement arthroplasty. Risk factors and treatment in sixty-seven cases. J Bone Joint Surg Am. 1990;72(6):878-83.

25. Kuster M, Sakurai S, Wood G. Kinematic and kinetic comparison of downhill and level walking. Clin Biomech. 1995;10(2):79-84.

26. Hong SW, Wang TM, Lu TW et al. Redistribution of intra-and interlimb support moments during downhill walking on different slopes. J Biomech. 2014;47(3):709-15.

27. Song CH, Shin WS, Lee KJ et al. The effect of a virtual reality-based exercise program using a video game on the muscle strength, balance and gait abilities in the elderly. J Korean Gerontol Soc. 2009;29(4):1261-75.

28. Sung SC, Lee MG. Effects of resistance and balance exercise training on isokinetic function, postural stability, and balance efficacy in elderly women. Korean J Sport Sci. 2007;18(4):21-33.

29. Lizaur A, Marco L, Cebrian R. Preoperative factors influencing the range of movement after total knee arthroplasty for severe osteoarthritis. J Bone Joint Surg Br. 1997;79(4):626-9.

30. Bade MJ, Kittelson JM, Kohrt WM et al. Predicting functional performance and range of motion outcomes after total knee arthroplasty. American journal of physical medicine \& rehabilitation/Association of Academic Physiatrists. 2014;93(7):579.

31. Heller F, Beuret-Blanquart F, Weber J. Postural biofeedback and locomotion reeducation in stroke patients. Ann Readapt Med Phys. 2005;48:187- 
95.

32. Bateni H. Changes in balance in older adults based on use of physical therapy vs the wii fit gaming system: a preliminary study. Physiotherapy. 2012;98(3):211-6.

33. Sihvonen SE, Sipilä S, Era PA. Changes in postural balance in frail elderly women during a 4-week visual feedback training: a randomized controlled trial. Gerontology. 2004;50(2):87-95.

34. Lee SR, Bae SS. Effects of virtual reality program on standing-balance in stroke with sensory deficit. Korean Soc Phys Med. 2010;5(1):63-70. 